\title{
Web-Based Education at Conventional Universi- ties in China: A Case Study
}

\author{
Weiyuan Zhang \\ Open University of Hong Kong \\ Jian Niu \\ China Central Radio and Television University \\ Guozhen Jiang \\ China Central Radio Television University
}

\begin{abstract}
With advances in information and communication technology (ICT), Webbased education has become an increasingly popular instructional mode all over the world. In recent years, the Chinese government has authorized a total of 45 universities to offer Web-based educational programs. One is China Central Radio and Television University, the Open University in China. The other 44 universities are all leading conventional universities. This case study is intended to provide a descriptive analysis of Web-based educational practices at the 44 leading conventional universities, by focusing on the current state of Web-based education in China and its discernible trends for the future. It is hoped this analysis of Web-based educational efforts in China will provide some insight for other countries.
\end{abstract}

\section{Introduction}

Regarded by many as a major form of advanced distance learning, the Chinese government has taken various measures to boost Web-based education. The Ministry of Education has launched a special project to achieve this particular purpose, the Modern Distance Education Project, and has provided the authority to a total of 45 universities to offer Web-based higher education programs nationwide. Among them is China Central Radio and Television University (CCRTVU), the Open University in China; the other 44 universities are all leading conventional universities.

Each of the 44 conventional universities has established a special Institute of Online Education to take exclusive charge of their Web-based higher education programs. The programs offered are primarily degree or diploma based and they are delivered via the Internet or the Web in conjunction with other media. 
Web-Based Education at Conventional Universities in China: A Case Study 2

Students are normally admitted based on a mixed system of free admission and entrance exam admission. They are also given a flexible time span for their course study.

Generally, Web-based education at the 44 leading conventional universities in China has been conducted smoothly. But as with other innovations, it has encountered problems and difficulties. In this article, the following issues will be examined: What are the major problems and difficulties encountered by students in accessing the Internet? What cost considerations are involved? How about the shortage of online instructional resources? Can the infrastructure in different universities be integrated to achieve economies of scale? Are external online learning support centers managed effectively? What training is needed to help instructors teach online courses effectively? Is web-based education extended to remote and poor areas? How about the accreditation of web-based education and the assurance of the quality of its graduates?

With the aim of providing a holistic and descriptive analysis of Web-based educational practices at the 44 leading conventional universities in China, this paper will start with a brief introduction to the societal and institutional contexts. It will then focus on the actual Web-based educational practices at the 44 conventional universities in terms of their course, student, regulatory, logistical, and the technological subsystems. The paper will then discuss some of the intended and unintended consequences of Web-based educational initiatives and examine future trends. Finally, the implications of Web-based education and its effect on higher education students, teachers, university administrators, and government policy makers will be discussed.

\section{Societal and Institutional Contexts}

\section{Country profile}

The People's Republic of China is situated in eastern Asia, and is bounded by the Pacific Ocean in the east. Being the third largest country in the world, it has an area of 9.6 million square kilometers, or one-fifteenth of the world's landmass. China has diverse types of land resources. There are more mountains than plains, with cultivated land and forests constituting only small portions. The land formation consists of 33 percent mountains, 26 percent plateaus, 19 percent basins, 12 percent plains, and 10 percent hills (CIIC, 2001). Most of China is in the temperate zone, although geographically it stretches from tropical and subtropical zones in the south, to the frigid-zone in the north.

There are 22 provinces, five autonomous regions, and four municipalities in mainland China. According to the latest results of the fifth national population census conducted by the Chinese government in November 2000, the total pop-

International Review of Research in Open and Distance Learning 
ulation of mainland China is 1.26583 billion, accounting for approximately 22 percent of the world's total population. China's urban population accounts for 36.09 percent, while the rural population make up the remaining 63.91 percent. The average annual population growth rate is 1.07 percent (National Bureau of Statistics, 2001a).

China is a unified, ethnically diverse country, comprising 56 ethnic groups. The Han makes up 91.59 percent of the total population, leaving 8.41 percent for the other 55 ethnic minorities.

Since the late 1970s, when the reform and opening-up drive was initiated, China's economy has been accelerating at a stead pace. This has resulted in significant improvements in China's standard of living. Table 1 and Table 2 provide a general picture of these great changes.

Table 1. GNP and GDP Increase in China, 1980 - 1999 (Unit: RMB100 million*)

\begin{tabular}{|l|l|l|l|}
\hline Year & $\begin{array}{l}\text { GNP } \\
\text { (Gross National Product) }\end{array}$ & $\begin{array}{l}\text { GDP } \\
\text { (Gross Domestic Product) }\end{array}$ & $\begin{array}{l}\text { GDP } \\
\text { per capita }\end{array}$ \\
\hline 1980 & 4517.8 & 4517.8 & 460 \\
\hline 1985 & 8989.1 & 8964.4 & 855 \\
\hline 1990 & 18598.4 & 18547.9 & 1634 \\
\hline 1995 & 57494.9 & 58478.1 & 4854 \\
\hline 1999 & 80422.8 & 81910.9 & 6534 \\
\hline
\end{tabular}

Source: Adapted from Statistical Yearbook of P.R China (2000)

* $1 \mathrm{US} \$ \approx 82 y \mathrm{ym}$ (RMB)

Regarding emerging information and communications technologies (ICT), China has experienced rapid growth in overall communication connectivity during the past two decades. According to the Ministry of Information Industry (MII, 2001a), by the end of 2000, residential telephone users will number 145,122 million, mobile phone users 85,26 million, and Internet users 16,017 million. The number of mobile phones per 1,000 persons was only 10 in 1997 (China Today, 2001), rising to 72 in December 2000, and 85 June 2001 (Ta Kung Pao, 2001). There were on average, 6 personal computers per 1,000 persons in 1997, (The World Bank, 2000) and 9.5 personal computers in 1999 (China Today, 2001).

According to the White Paper on Population in China, issued by the Information Office of the State Council in 2000, the population living below the poverty line 
in China's rural areas, decreased from over 250 million in the late 1970s, to approximately 34 million in 1999 . This reflects a 33 percent drop in rural poverty rates. Today, impoverished people living in rural areas have basically achieved adequate levels in terms of feeding and clothing, and the average life expectancy has increased to 71 years. According to the fifth national population census conducted in November 2000, just over eighty-five million of China's 1.26583 billion citizens living on the mainland are considered illiterate (i.e., adults over 15 years of age who cannot read or can read very little). This can be compared to data collected during forth-national population census conducted in 1990, which reflected an illiteracy rate of 15.88 percent. In the course of ten years, China's illiteracy rate has dropped 9.16 percentage points, to 6.72 percent.

Despite these noteworthy advancements, China is still a developing country. Not only does China have the largest population on Earth, it is supported by a weak economic foundation, as reflected in relatively inadequate resources per-capita. Furthermore, economic development is regionally unbalanced. China's western regions and inland areas are generally less well developed than its eastern regions and coastal areas. These are the basic national conditions of China, and these

distinctive features and contexts must be taken into full account when policies concerning China's economic and social development - including education are made.

\section{General Higher Education}

Higher education in China consists of general higher education and adult higher education. General higher education is offered by China's conventional universities and colleges, and caters to senior secondary school graduates. Adult higher education, on the other hand, targets working adults and is offered by conventional universities and colleges and by institutions that specialize in adult higher education such as China Radio and Television Universities (China RTVUs, the Open University system in China), staff training colleges, educational colleges, etc., (Yang, 2001a).

General higher education in China comprises junior college, Bachelor's, Master's and Doctoral degree programs. The duration of junior college programs is two to three years, depending on the subject area studied. Bachelor programs generally last four years (medical and some engineering and technical programs, five years). Graduate degrees, such as Master's degree programs take two to three years additional study, after which Doctoral programs take another three. Students are normally admitted to higher education degree programs, including Masters and Doctorates, by passing relevant national entrance examinations. The average age of students participating in junior college is $18-20$; the average age of students participating Bachelor degree programs is $21-22$ years. Entrants are generally senior secondary school graduates. Upon the successful

International Review of Research in Open and Distance Learning 
completion of a junior college program, students are awarded a higher diploma in their related subject areas.

Table 3 below provides some details on the development of general higher education offered by China's conventional universities and colleges in the years 1985 to 2001.

Table 3 above shows that general higher education in China has been developing at a steady pace. The most significant changes, though, took place in 1999 when the Chinese government expanded higher education dramatically. This fact is noted in Table 3, which shows that nearly a half million new higher education students have been admitted since 1999. According to the Action Scheme for Invigorating Education Towards the 21st Century (MOE, 1999), drafted by the Ministry of Education in 1998 to officially guide the overall educational development in China (and formally approved by the State Council of People's Republic of China in 1999), one strategic objective is to increase university participation rates by 15 percent by 2010. Thus it is natural to expect considerable growth occurring in China's higher education sector now and in the years to come.

Two primary reasons contributing to the dramatic expansion of higher education in China since 1999 have been identified (Lin, 2001; Yang, 2001). One reason is that the system of higher education in China, due to its historically limited and restrictive features, could no longer keep up with increasing demand. Expansion, therefore, will make it possible for more people (especially senior secondary school graduates) to have access to higher education opportunities. Another reason is that expansion in higher education is expected to stimulate economic growth, as students will be required to pay for their higher education. At a time of global economic downturns, stimulating educational spending is anticipated to help boost China's economy.

\section{Distance Education by Conventional Universities and Colleges}

Distance education in China has evolved through three stages: correspondencebased education; broadcasting/television-based education since the 1980s; and advanced distance learning based on information and Internet technologies since the 1990s (CERNET, 2001d). The third stage is still in the embryonic phase, but is experiencing rapid growth and development in China.

Distance education in China, is offered by two types of educational institutions: single-mode open universities and various distance education colleges, schools, departments, and sections found in conventional universities and colleges. An example of a single-mode open type, are China's radio television universities.

International Review of Research in Open and Distance Learning 
The latter type are found in different conventional universities and colleges, and given different names such as adult education college, correspondence education department, institute of online education, etc.

In fact, most of the conventional universities and colleges in China set up distance education colleges, schools, or departments since they were established. In other words, most conventional universities and colleges in China are dual mode institutions offering conventional face-to-face instruction to regular oncampus students, while at the same time offering distance learning programs and courses to off-campus students who are mostly working adults studying part time. The major teaching-learning modes are correspondence instruction and weekend or evening classes. These programs may be degree-based or simply training-oriented.

\section{Web-Based Education at Conventional Universi- ties}

\section{Background and a Chronicle of Efforts}

As is true elsewhere, the exponential growth in information and communication technologies has had a profound effect on China's higher education system. Web-based education is becoming an increasingly popular instructional mode. As part of its drive to expand higher education to the benefit of its entire population, in recent years the government has engaged in various measures to boost Web-based education, primarily because it is viewed as a major component in the construction of nationwide open education network and lifelong learning system (MOE, 1999). For example, in the Action Scheme for Invigorating Education Towards the 21st Century, a new project called the Modern Distance Education Project was launched with the objective of making full use of the modern ICT to extend China's limited educational resources outwards to help reach its vast population. The developmental focus of this project is Web-based education.

China's leading conventional universities have responded quickly and enthusiastically to this government initiative. As part of its efforts to implement the Modern Distance Education Project and to help promote Web-based education, Hunan University, in cooperation with Hunan Telecom, established China's first online university in 1997. In 1998, Tsinghua University launched an online Master's program. In July 2000, the Ministry of Education released the document, Provisional Administration Methods for Educational Websites and Online Schools, thereby enunciating its jurisdiction over educational Websites and Web-based schools. Shortly thereafter, the Ministry granted online learning licenses to 31 universities in China, including the China Central Radio and Tele-

International Review of Research in Open and Distance Learning 
vision University (CCRTU), the academic headquarters of China RTVUs. The Ministry then issued Several Comments on Supporting Some Universities and Colleges to Set up Institutes of Online Education to Pioneer distance learning, a document that announced substantial autonomy for the 31 universities pioneering Web-based instruction initiatives. Universities that have been granted licenses are now allowed to establish their admission gateways and determine admission quotas. They are also allowed offer programs both in and outside of the subject catalogues produced by the Ministry of Education. They can also award certificates, diplomas, or degrees formally recognized by the government, plus they are authorized to establish external online learning support centers (CERNET, 2001d).

According to the latest statistics from the Ministry of Education (MOE, 2001b), a total of 45 universities (CCRTVU and 44 leading conventional universities) have been granted online learning licenses by the Ministry of Education. By March 2001, the total number of students enrolled in various programs at these 45 universities reached over 240,000 (180,000 students at CCRTVU and 65,000 students at 44 conventional universities) (Yin and Lu, 2001). By September 2001 , this number is expected to reach $400,000(\mathrm{Fu}, 2001)$. In addition, the first batch of online students graduated in July 2001, when 255 out of the 308 students enrolled in the Bachelor business administration program successfully completed their studies at the Institute of Online Education at Zhejiang University. This number reflects a program completion rate of 82.8 percent (Pan, 2001).

To provide a clearer picture of Web-based education in China today, the discussion that follows will focus on five subsystem of the 44 leading conventional universities: (1) course, (2) student, (3) regulatory, (4) logistical, and (5) technological.

\section{The Course Subsystem}

According to Huang (2001), current Web-based educational programs offered by the 44 leading conventional universities in China are either at the diploma or degree level. The programs can be divided into five types. Postgraduate diploma programs cater to Bachelor degree graduates either from conventional universities and colleges, or from adult higher education institutions. So far, only Tsinghua University, Beijing Institute of Technology and Shanghai Jiaotong University offer this type of online learning program. In the Bachelor programs offered by 92 percent of the 45 providing universities (including CCRTVU), students gain admission with a junior college higher diploma. The other three types include a second Bachelor degree program, a Bachelor program starting

with a senior secondary school certificate, and a junior college higher diploma program. These five types of Web-based programs have been extended to all 31 provinces, autonomous regions, and municipalities across China's mainland

International Review of Research in Open and Distance Learning 
(Yin and $\mathrm{Lu}, 2001$ ).

The 45 online learning providers (including CCRTVU) offer a total of 51 specialties in eight subject areas (Yin and $\mathrm{Lu}, 2001$ ). Computing Science and Technology and Business Administration are most the popular, with 76 percent of the 45 providing universities (including CCRTVU) offering these two specialties. In addition, 60 percent of the 45 providing universities (including CCRTVU) offer Finance programs, and 48 percent offer English and Law. The provision of these popular specialties indicates high demand for professionals in these job areas (Huang, 2001).

In terms of the teaching and learning modes adopted by the 45 online learning providers (including CCRTVU), Huang (2001) broadly classifies them into two kinds. One kind is defined as "distance real-time instruction mode," or simply "live transmission classroom + online self-study courseware + online discussion and problem solving + tutorial support at a study center." This mode has a higher hardware and technical support requirements. Tsinghua University, Shanghai Jiaotong University, South China University of Technology (Guangzhou) and China Central Radio and Television University all engage in this particular teaching and learning mode. The second kind is termed by Huang (2001) as "distance self-study courseware instruction mode," or more simply "self-study courseware + online discussion and problem solving + tutorial support at a study center." This mode requires less hardware and technical support and is used in universities such as Renmin University of China (Beijing), Beijing Foreign Studies University and Southeast University (Nanjing).

In terms of course material provision, most of the 44 leading conventional universities strive to offer a variety of media choices to students. For example, the Institute of Online Education at Beijing Foreign Studies University provides print materials, audiotapes, videocassettes, VCDs and CAI coursewares as an integrated learning package to its Bachelor of English students. Course materials offered by these universities typically include print (textbooks), coursewares (CD-ROM version and/or online version) and online courses. These materials are either specially prepared for Web-based educational programs, or borrowed from regular traditional programs.

In terms of course material delivery, the 44 leading conventional universities normally deliver course materials to online to their learning support centers across the country, where students are then notified to pick them up at a location convenient to them. The other delivery method is to post course materials directly to the students' homes or place of work. As for the materials delivered online, students can access them via their own computer at home or at work, or at computer study labs located at their local learning support centers.

International Review of Research in Open and Distance Learning 
Web-Based Education at Conventional Universities in China: A Case Study 9

\section{The Student Subsystem}

In terms of student admission to different online learning programs, China's 44 leading conventional universities participating in Web-based programming usually employ a mixed measure of free admission and entrance exam admission. Table 4 below summarizes the admission policies of these 44 conventional universities.

Most of the 44 conventional universities adopt a flexible credit system based on different lengths of study, depending on the online learning program pursued by students. Table 5 below provides a summary of the credit system generally followed by these universities.

Students participating in Web-based programs at 44 conventional universities usually pay fees for tuition, course materials, make-up exams, degree applications, certificate production, English exams, and entrance exams. Tuition accounts for the largest percentage of all fees charged. According to Huang and Luo (2001), due to regional differences in economic development, tuition fees vary from university to university. Universities in South China charge the highest fees, universities in Shanghai rank second, and those in Beijing rank third. Tuition fees in Central and Western China are the lowest. For example, total tuition fees for a Web-based Bachelor program starting with a senior secondary school certificate are 36,000 yuan in South China, 28,000 yuan in Shanghai, 18,000 yuan in Beijing, and 10,000 yuan in Northwestern China.

\section{The Regulatory Subsystem}

China's 44 leading conventional universities have attached great importance to Web-based education ever since they received authority from the Ministry of Education to run online learning programming. All have established within their university's existing organizational structure new departments to take exclusive charge of Web-based educational programming. In most cases, these departments are called: "Institutes of Online Education." Regulatory requirements established by the Ministry of Education, deem that the chief university officer take full charge of their university's online institute. For instance, at Beijing Foreign Studies University, its President is also the Dean of its Institute of Online Education.

Structurally parallel to other academic departments and administrative bodies within the university, these Institutes of Online Education usually are comprised of the following units: General Office, Student Recruitment and Admission Section, Teaching Administration Section, Student Management Section, Course Development Section, Technical Support Section, and Finance Section. In addition, the Institute of Online Education has external online learning support and study centers located across the country.

International Review of Research in Open and Distance Learning 
Web-Based Education at Conventional Universities in China: A Case Study 10

In terms of the delegation of responsibility, the General Office of the Institute of Online Education provides general clerical support to its staff and students. The Student Recruitment and Admission Section is in charge of student admissions and entrance exams. The Teaching Administration Section is responsible for teaching affairs, including tutorial sessions, and tutor recruitment and management. The Student Management Section is in charge of student affairs, including registration, and student support and counseling. The Course Development Section is accountable for instructional materials, courseware, and online course development. The Technical Support Section provides technical support for course delivery, systems maintenance, and courseware development. The Finance Section oversees the financial affairs of the institute.

There are few full-time staff members in the Institutes of Online Education at the 44 conventional universities, most having been transferred or on loan from other academic departments within the university. In some universities, there are only about 10 full-time staff members working in the Institute of Online Education. As a result, most staff members engaged in Web-based education (and more broadly distance education) are new to teaching online.

\section{The Logistical Subsystem}

The Technical Support Sections in the Institutes of Online Education are responsible for the purchase, development, and maintenance of their university's instructional delivery system. The General Office, Student Management Section, Finance Section, and other sections provide logistical support to ensure the smooth operation of the whole institute. The Dean of the institute acts as general coordinator for different departments and sections inside and outside the institute.

\section{The Technological Subsystem}

To shorten the distance between tutor and student and to enhance two-way tutor-student communication, most of the 44 conventional universities have strived provide a variety of modern transmission and interactive technologies in conjunction with the Internet. Table 6 illustrates some examples of integrated ICT use at some key conventional universities in China. The data gathered is from the homepages and brochures of the universities listed.

International Review of Research in Open and Distance Learning 
Web-Based Education at Conventional Universities in China: A Case Study 11

\section{Intended and Unintended Consequences}

\section{Intended Consequences}

In spite of its rapid growth, advanced distance learning based on emerging information and communication technologies is still in its early stage in China. Now considered a major form of advanced distance learning, Web-based education is becoming popular both at the single-mode distance teaching universities such as China RTVUs, and at the duel-mode conventional universities. Webbased educational modes practiced at China's 44 leading conventional universities, has produced a positive effect on the country's higher education sector. Firstly, Web-based education has provided a new path to people desiring access to higher education, and is thereby seen as contributing to the government's goal of popularizing higher education among its vast population. Secondly, Web-based education has increased and extended the use of the educational resources developed by conventional universities. Quality educational resources are being shared online by staff and students via the Internet, serving a much larger learner cohort than was previously possible in campus-based situations. Thirdly, Web-based education has provided new ways of thinking and new methods of teaching and learning. In the past, conventional universities had been characterized by a combination of textbook learning and "chalk and talk," a dynamic where teachers plays the central role in the classroom while students remain passive learners. With the introduction of the Web-based instructional mode, teachers and students now find the multimedia course materials more interesting and stimulating. Students have more autonomy in their own learning, and teachers play a more significant role as facilitators. At Hunan University, for example, on-campus students are now using Web-based courses and learning materials originally intended for its Institute of Online Education students, thereby creating a greatly amplified benefit. Due to the generally positive outcomes Web-based education has produced for its higher education system, the Ministry of Education has decided that more conventional universities will be authorized to offer online learning programs as part of its lifelong learning system in China ( $\mathrm{Fu}, 2001)$.

\section{Discernible Trends}

Based on the practices at the 44 leading conventional universities, three trends can be identified in the provision of Web-based education in China today. One trend is that Web-based educational programs are usually offered jointly by the providing university and by an external enterprise. The university normally takes charge of instructional affairs, whereas the enterprise contributes in terms of funding, technology, and marketing. For example, Beijing University of Posts and Telecommunications joins hands with China Telecom to offer Web-based

International Review of Research in Open and Distance Learning 
Web-Based Education at Conventional Universities in China: A Case Study 12

programs. Beijing Foreign Studies University offers a Web-based Bachelor of English program in partnership with Pacific Century Cyberworks (PCCW) in Hong Kong. It is thus evident that Web-based education has promoted, and will continue to promote, integration and cooperation between universities and enterprises.

A second trend, observed in some of the 44 conventional universities (e.g., Tsinghua University and Zhejiang University) is the establishment of external online learning support centers at local China RTVU study centers. Web-based education has thus enhanced cooperation between traditional universities and distance teaching institutions, although it should be admitted that the competition between them is increasing. However, according to Jiang (2001), two major conditions will work to promote increased cooperation over that of competition. First, traditional universities are strong in their access and production of quality educational resources. Secondly, China's RTVUs are strong in their system networking, and learning support and learner management services. Cooperation, therefore, benefits both sides. Another reason is that the higher education market in China is so enormous, it will remain a sellers-market for the foreseeable future.

A third trend involves the design and development of multimedia integrated course delivery packages. There is broad consensus that the Internet is only one medium for instructional delivery. Therefore, where appropriate, Web-based instruction will be supported by other instructional media such as: print materials, audiotapes, videocassettes, radio and TV programs, VCDs, CD-ROM coursewares, etc. It will also be supported, where necessary, by other instructional means such as tutorial sessions, pair work, group work, etc.

\section{Unintended Consequences and Problems Encountered}

As with any other innovation, Web-based education in China has encountered problems and difficulties despite its rapid development. A careful analysis shows that six major problems remain and yet to be resolved.

The first problem is that many students simply do not have access to computers or the Internet at home, as is particularly the case for students from poor families. Even if students do have a computer and Internet access at home, bandwidth may be so narrow, and download times so slow, they often lose patience. Cost is another barrier to access. The price for the Internet access is still relatively high in China, therefore many students simply cannot not afford Web-based education as a chief way of completing their years-long program of study. Official charges for a dial-up Internet access in China currently stand at 4 yuan per hour for the first 60 hours. If the surfing time stretches beyond 60 hours, charges rise to 8 yuan per hour. In addition, students must also pay local calling fees over and above their Internet access fees. Local calling fees

International Review of Research in Open and Distance Learning 
Web-Based Education at Conventional Universities in China: A Case Study 13

vary in different parts of China. For example, in Beijing the local calling fee is 5.4 yuan per hour (see Table 2 for the average annual salary of an employee in China). And while there is 50 percent discount on Internet dial-up charges during non-peak hours (23:00-8:00 on work days and 0:00-24:00 on public holidays and weekends) (MII, 2001b; CNNIC, 2001), it remains prohibitively expensive for many students. Finally, universities that offer Intranet facilities where the students can engage in online learning, (in reality the most popular practice at the moment at all of the 44 leading conventional universities) many students still face problems of access due to time and place constraints on part of both students and providing institutions.

The second problem concerns the shortage of online instructional resources and duplication of online programs. At present, all of the 44 conventional universities are investing heavily in hardware. But there still remains a shortage of appropriate software and courseware resources. Many of the 44 conventional universities offer similar specialties and course offerings, each requiring substantial investments in course research and development. This has led to the duplication of resource materials produced by these universities, thereby creating unnecessary waste in terms of human and financial resources. Coordination, therefore, is necessary to conserve resources and to promote the leveraging and sharing of high-quality educational resources among different universities.

The third problem concerns the effective management of external online learning support centers located both on-campus and at locations across the country. Normally these centers are based in other educational partner institutions. A key issue for expansion of Web-based education, therefore, is determining how best to establish and maintain constructive and mutually beneficial relationships between partner institutions to ensure effective learning and student support.

The fourth problem concerns teacher training at each of the Institutes of Online Education. As mentioned earlier, staff members working at these institutes mostly transfer in, or are on loan, from other academic departments. Because Web-based education, or more broadly distance education, is partially or totally a new thing to many of these teachers, training is an urgent task facing these universities. Without adequate training, it is hard to expect teachers to produce top quality online learning materials and provide top quality learning support to students.

The fifth problem concerns the extension of Web-based education to learners in remote and economically disadvantaged areas in China. So far, students enrolled in Web-based educational programs are mostly (if not all) from urban and rich areas. The bigger problem facing China's vast population wishing to gain access to higher education, therefore, is to "how to send coal to those in the snow." It should be borne in mind, at this point, that one significant advantage of Webbased education, at least in theory, is that it can free learners from time and place constraints, thereby extending quality education to anybody anywhere.

International Review of Research in Open and Distance Learning 
Web-Based Education at Conventional Universities in China: A Case Study 14

The sixth, and perhaps most sensitive, problem concern the credibility of Webbased education and the quality of its graduates. To date, there have not been many graduates from the Institutes of Online Education at the 44 conventional universities, therefore questions as to credibility and quality can hardly be answered at this time. However, the issue has attracted wide attention throughout China (Liu, 2001; Xiao, 2001).

\section{Implications}

Although Web-based education as practiced by China's conventional universities has only enjoyed a short history, it has produced profound implications for the higher education students, teachers, administrators, and government policy makers. Students engaging in Web-based programs must first to familiarize themselves with the use of the computer and the Internet. Basic computer and Internet literacy is essential if students are to become autonomous and effective online learners.

For teachers, they face problems similar to those facing their students. Like their students, teachers must first attain basic computer and Internet literacy skills. They must also learn Web-based teaching strategies and hone their online teaching skills. Most importantly, they need to transform their traditional role from that of simply a course lecturer to that of an all-round helper, so they can provide their students with ongoing support starting from pre-course inquiry through to course completion (Granger and Benke, 1998).

For university administrators, investment in hardware and software development is obviously important. But in the Web-based instructional context, learner and teacher support is equally important. Student support initiatives and human resource development is therefore essential.

For government policy makers, three issues require their urgent and long-term persistent attention. One issue is determining the role of government will play in enabling China's universities to extend Web-based education to its vast poor regions. A second issue is determining how the government can effectively coordinate the efforts of different universities to avoid unnecessary duplication in the design and development of quality educational material. They must also promote the leveraging and sharing of educational resources among institutions. A third issue is determining how the government can best encourage the maintenance of uniform and high-quality standards in Web-based educational programming.

With respect to the implications for further distance education research, two areas are of interest and value both to China and to other countries. One area relates to the effectiveness of online teaching and learning. Another area relates to how intra- and inter-institutional collaboration might be promoted effectively

International Review of Research in Open and Distance Learning 
Web-Based Education at Conventional Universities in China: A Case Study 15

so that Web-based education can bear satisfactory fruits for all.

\section{Conclusion}

The purpose of this article has been to present the experience of the 44 conventional universities that have been authorized by the government to establish online educational programs. While still in the experimental stage, these universities face many challenges in the development of an effective, efficient, and user-friendly Web-based instructional model. Clearly much in-depth research needed in this area, now and in the future. As a senior official from China's Ministry of Education said: "I will be in charge of developing 300 Web-based courses in the year of 2000. However, very little research has been conducted so far on Web-based education in China and it is very difficult for us to develop so many Web-based courses of good quality and with cost effectiveness in a short time. But the government has decided to invest a huge amount of money on it and this has placed a lot of pressure upon me" (Personal interview with an official from the Ministry of Education in China, on 13 August 1999). 
Web-Based Education at Conventional Universities in China: A Case Study 16

\section{References}

Beijing Institute of Technology. (2001). Enrollment Announcement for Modern Distance

Education Programs 2001. [Retrieved December 2001: http:// learn.bit.edu.cn /sde/recruit/ graduate_2001.htm. ]

China Education and Research Network (CERNET) (2001a). Statistics on China Education. [Online] Retrieved September 2001: http: //www.edu.cn/ zhong-guo-jiao -yu /shu-zi/xuexiao/putong99.php.

China Education and Research Network (CERNET) (2001b). Basic Statistics on Education. [Online] Retrieved September 2001: http: //www.edu.cn /english/ statistics/edu /edu_99_01. php.

China Education and Research Network (CERNET). (2001c). Education Development.

[Online] Retrieved September 2001: http:// www.edu.cn /zhong_guo_jiao_yu/ shu_zi/index. php.

China Education and Research Network (CERNET) (2001d). Advanced Distance Learning. [Online] Retrieved September 2001: http: //www.edu.cn /english /education /distance/ intro/dis_05. php.

China Internet Information Centre (CIIC) (2001). China - Quick Facts. [Online] Retrieved December 2001: http:// www.china. org.cn/e-changshi/ index.htm.

China Internet Network Information Centre (CNNIC) (2001). . Statistical Report of the Development of China Internet Network (July 2001). [Online] Retrieved December 2001: http: //www.cnnic. net.cn/develst/ rep200107-1. shtml.

China Today. (2001). Statistics and Data at Hand. [Online] Retrieved September 2001: http:// www.chinatoday .com/data/ data.htm\#Tel.

Department of Development and Planning (DDP), Ministry of Education, PRC (2001). Major Figures and a Brief Analysis of National Education Development in 2000. [Online] Retrieved September 2001: http ://www. edu.cn /20010910/3000909.shtml.

$\mathrm{Fu}$, Zhengguo (2001). Students registered for university online learning programs will reach 400,000. The People's Daily (6 September 2001).

Granger, D. \& Benke, M. (1998). "Supporting Learners at a Distance from Inquiry through Completion," in Gibson, C. C (Ed.), Distance Learners in 
Web-Based Education at Conventional Universities in China: A Case Study 17

Higher Education: Institutional Responses for Quality Outcomes. Madison, WI: Atwood Publishing, 127-137.

Huang, Ronghuai (2001). A Direct Look at Web-based Education. China Education Daily (25 November 2001).

Huang, Ronghuai \& Luo, Xiaochun (2001). Reflections on the modern distance education practice at conventional universities. China Distance Education, Vol.9, 2001, 38-39.

Hunan University (2001). Enrollment Announcement for Modern Distance Education Programs 2001. [Online] Retrieved December 2001: http:// www.nip. net.cn/ home/ zszl_5. htm.

Information Office of the State Council, PRC (2001). White Paper on Population in China (2000). [Online] Retrieved September 2001: http: //www.sfpc. gov.cn/en/whitepaper .htm.

Jiang, Guozhen (2001). Diversification of higher education and development of China RTVUs. China Distance Education, Vol.7, 2001, 36-37.

Lin, Xi (2001). Enrollment Expansion at Conventional Universities and Colleges Contributes 7 Billion Yuan to National Economic Growth. [Online] Retrieved December 2001: http:// 203.207.146. 1/forum/ doc/zjar/ 200104176172. htm.

Liu, Yu (2001). What's Wrong with Online University Diplomas when Job Applications are Rejected Once and Again? China Education Daily (20 November 2001).

Ministry of Education, PRC (MOE) (2001a). . List of Conventional Universities and Colleges in China. [Online] Retrieved December 2001: http:// www.moe. edu.cn /highedu /gxtz/gxmd. htm.

Ministry of Education, PRC (MOE) (2001b). Tightening the Management of the Admission Work for the Modern Distance Education Pilot Program. [Online] Retrieved September 2001: http:// www.moe.edu.cn/Webdoc/news/ 010824-02.htm.

Ministry of Education, PRC (MOE) (2000). Bulletin of Statistics on National Education Development in 1999. [Online] Retrieved September 2001: http: //www.moe.edu.cn /moe-dept/ fazhan/index .htm.

Ministry of Education, PRC (MOE) (1999). Action Scheme for Invigorating Education Towards the 21st Century. [Online] Retrieved September 2001: http: //www.edu .cn/english / education /law/ law_index .php.

Ministry of Information Industry, PRC (MII) (2001a). Bulletin of Statistics on China Telecommunications in 2000. [Online] Retrieved September 2001: 
Web-Based Education at Conventional Universities in China: A Case Study 18

http: //www.mii.gov .cn/mii/hyzw/2000 gongbao .htm.

Ministry of Information Industry, PRC (MII). (2001b). Adjusted Charges for Internet Users since 1999. [Online] Retrieved September 2001: http: //www.mii. gov.cn/mii /hyzw/zifei/ tztz_6. htm.

National Bureau of Statistics, PRC. (2001a). Major Figures of the 2000 Population Census (No. 1). [Online] Retrieved September 2001: http ://www.sfpc. gov.cn/en/5cendata.htm.

National Bureau of Statistics, PRC (2001b). Statistical Yearbook of P.R. China (2000b).

[Online] Retrieved September 2001: http: //www.stats. gov.cn/sjjw/ndsj/ zgnj/2000/ C01c.htm.

National Bureau of Statistics, PRC (2001c). Statistical Yearbook of P.R. China (2000c).

[Online] Retrieved September 2001: http: //www.stats .gov.cn/ sjjw/ndsj/ zgnj/2000/ J01c.htm.

National Bureau of Statistics, PRC (2001d). Statistical Yearbook of P.R. China (2000d).

[Online] Retrieved September 2001: http: //www.stats .gov.cn/sjjw /ndsj/zgnj/ 2000/ T01c.htm.

National Center for Education Development Research (NCEDR), Ministry of Education, PRC. (2001). Green Paper on education in China (2000). Beijing: Educational Science Press.

Pan, Jiankai (2001). The first batch of distance learning students graduated from Zhejiang University. Guangming Daily (28 July 2001, A2).

Qu, Zhenyuan (2001). A summary of new students" admission work at higher education institutions in 2001 and future working guidelines. China Education Daily (5 December 2001).

Renmin University of China (2001). Enrollment Announcement for Modern Distance Education Programs 2001. [Online] Retrieved December 2001: http: //www.cmr.com .cn/distance /eduinfo/ zsjz.htm.

Southern Yangtze University (2001). Enrollment Announcement for Modern Distance Education Programs 2001. [Online] Retrieved December 2001: http ://www.cmjnu.com .cn/netschool/ zsjz.htm.

Ta Kung Pao (Tai Kung Daily). (21 June 2001, C2). Mobile phone users in China reach 110 million. Hong Kong.

International Review of Research in Open and Distance Learning 
Web-Based Education at Conventional Universities in China: A Case Study 19

The World Bank (2000). Entering the 21st century: world development report 1999/2000. Oxford, UK: Oxford University Press.

Xiao, Lin (2001). Most employers say "yes" to graduating students from Webbased programs. Beijing Evening News (14 November 2001).

Yang, Dongping (2001a). Higher Education in China. [Online] Retrieved December 2001: http: //www.edu.cn/20010827/208329 .shtml.

Yang, Dongping (2001b). Report on China Education Development in 2000. [Online] Retrieved September 2001: http: //www.edu.cn / special/ showarticle $\cdot$ php?id= 232 .

Yang, Ping (2001). A rational thinking about the higher education expansion and economic growth. Education, Vol.5, 2001.

Yin, Hongzhu \& Lu, Nuo (2001). The Ministry of Education Takes Solid Actions to Boost Modern Distance Education. [Online] Retrieved December 2001: http:// $202.205 .160 .5 /$ suxin2/read.php? id=102.

Zhejiang University (2001). Enrollment Announcement for Modern Distance Education Programs 2001. [Online] Retrieved December 2001: http: //www. zjuyc.com/ zdyc/zszl/ 2001zsjz .htm.

Citation Format

Zhang, Weiyuan, Niu, Jian \& Jiang, Guozhen (January, 2002) Web-Based Education at Conventional Universities in China: A Case Study. International Review of Research in Open and Distance Learning: 2, 2. http://www.icaap.org/iuicode?149.2.2.8 
Web-Based Education at Conventional Universities in China: A Case Study 20

Table 2: Living Standards in China, 1985 - 1999

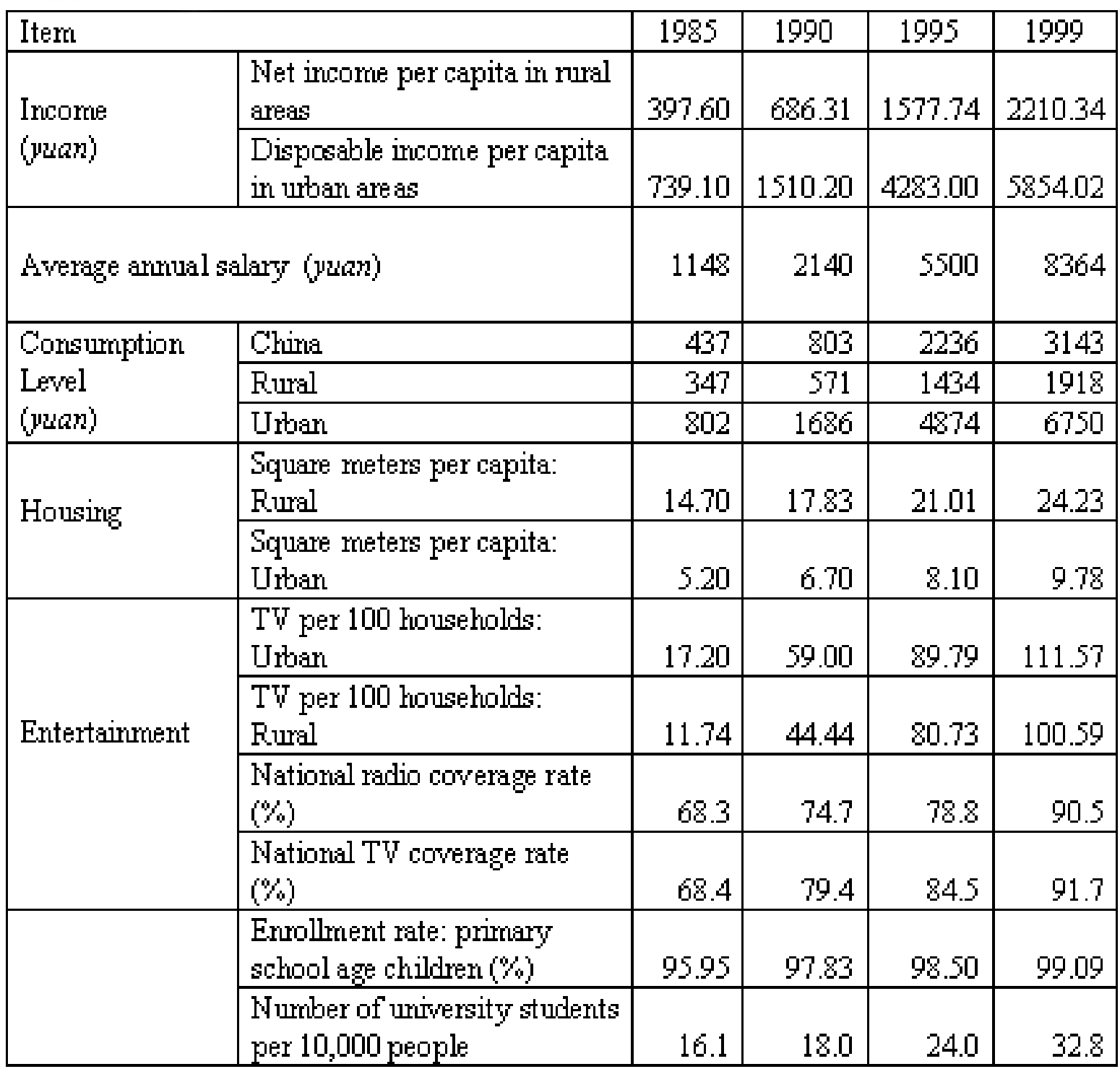

Source: Adapted from Statistical Yearbook of P.R China (2000) 
Web-Based Education at Conventional Universities in China: A Case Study 21

Table 3: Development of General Higher Education in China, 1985 2001

\begin{tabular}{|l|c|c|c|c|c|c|c|}
\hline \multicolumn{1}{|c|}{ Year } & 1985 & 1990 & 1995 & 1998 & 1999 & 2000 & 2001 \\
\hline $\begin{array}{l}\text { Nurmber of conventional } \\
\text { universities and colleges }\end{array}$ & 1016 & 1075 & 1054 & 1022 & 1071 & 1041 & 1166 \\
\hline $\begin{array}{l}\text { Full-time teachers / per 10,000 } \\
\text { persons }\end{array}$ & 34.4 & 39.5 & 40.1 & 40.7 & 42.6 & 46.28 & N/A \\
\hline $\begin{array}{l}\text { New studerts admitted to } \\
\text { Diploma and BA programs i per } \\
10,000 \text { persons }\end{array}$ & 61.9 & 60.9 & 92.6 & 108.4 & 159.7 & 220.6 & 260.0 \\
\hline $\begin{array}{l}\text { Nurber of students errolled in } \\
\text { Diploma and BA programs i per } \\
10,000 \text { persons }\end{array}$ & 170.3 & 206.3 & 290.6 & 340.9 & 433.2 & 556.1 & 712.0 \\
\hline $\begin{array}{l}\text { Diploma and BA graduates i per } \\
10,000 \text { persons }\end{array}$ & 31.6 & 61.4 & 80.5 & 83.0 & 84.8 & 94.98 & N/A \\
\hline
\end{tabular}

Hote: N/A: Data not available.

Data sources taken from CERHET (2001 a;2001b; 2001 c), DDP (2001), MOE (2000;2001 a), HCEDR (2001), Qu (2001), Statistical Yearbook of P.R Ohina (2000d) and Yang (2001a; 2001b). 
Web-Based Education at Conventional Universities in China: A Case Study 22

Table 4: Admission Policy for Web-based Educational Programs

\begin{tabular}{|c|c|c|}
\hline Program Types & Admission Methods & $\begin{array}{c}\text { Academic } \\
\text { Qualifications }\end{array}$ \\
\hline $\begin{array}{l}\text { Postgraduate Diploma } \\
\text { Program }\end{array}$ & - Free admission & $\begin{array}{l}\text { Bachelor degree plus } \\
\text { three years work } \\
\text { experience }\end{array}$ \\
\hline $\begin{array}{l}\text { Second Bache lor } \\
\text { Degree Program }\end{array}$ & - Free adrussion & $\begin{array}{l}\text { Bachelor degree and } \\
\text { higher }\end{array}$ \\
\hline $\begin{array}{l}\text { Bachelor Program } \\
\text { starting with a Junior } \\
\text { College Higher } \\
\text { Diploma }\end{array}$ & $\begin{array}{l}\text { - Free admission; or } \\
\text { - Entrance exam }\end{array}$ & $\begin{array}{l}\text { Jurior college higher } \\
\text { diploma and higher }\end{array}$ \\
\hline $\begin{array}{l}\text { Bachelor Program } \\
\text { starting with a Serior } \\
\text { Secondary School } \\
\text { Certificate }\end{array}$ & \multirow{2}{*}{$\begin{array}{l}\text { - Passing grade in the National } \\
\text { Entrance Exams for Corventional } \\
\text { Higher Education Institutions } \\
\text { administered by the government; } \\
\text { or } \\
\text { - Passing grade in the National } \\
\text { Entrance Exam for Adult Higher } \\
\text { Education Institutions } \\
\text { adrimistered by the government; } \\
\text { or } \\
\text { - Entrance exam }\end{array}$} & \multirow[t]{2}{*}{$\begin{array}{l}\text { Senior secondary } \\
\text { school certific ate and } \\
\text { higher }\end{array}$} \\
\hline $\begin{array}{l}\text { Junior College Higher } \\
\text { Diploma Program }\end{array}$ & & \\
\hline
\end{tabular}

* (Beijing Institute of Techmobgy, 2001; Human University, 2001; Rermin University of China, 2001 ; Southem Yangtze University, 2001; Zhejiang University, 2001). 
Web-Based Education at Conventional Universities in China: A Case Study 23

Table 5: Credit System and Periods of Study for Web-based Educational Programs

\begin{tabular}{|c|c|c|c|}
\hline Academic Programs & Credit Requirements & $\begin{array}{l}\text { Minimum Study } \\
\text { Period } \\
\end{array}$ & $\begin{array}{l}\text { Maximum } \\
\text { Study Period } \\
\end{array}$ \\
\hline $\begin{array}{l}\text { Post-graduate } \\
\text { Diploma Program }\end{array}$ & $32-40$ credits & 2 years & 4 years \\
\hline $\begin{array}{l}\text { Bachelor Program } \\
\text { starting with a } \\
\text { Junior College } \\
\text { Diploma }\end{array}$ & $\begin{array}{c}100 \text { credits } \\
\text { (approx.) }\end{array}$ & \multirow{2}{*}{2 years } & \multirow{2}{*}{5 years } \\
\hline $\begin{array}{l}\text { Second Bache lor } \\
\text { Degree Program; or } \\
\text { Jurior College } \\
\text { Diplorna Program }\end{array}$ & $\begin{array}{l}80 \text { credits } \\
\text { (approx.) }\end{array}$ & & \\
\hline $\begin{array}{l}\text { Bachelor Program } \\
\text { starting with a } \\
\text { Senior Secondary } \\
\text { School Certificate }\end{array}$ & $\begin{array}{l}170 \text { credits } \\
\text { (approx.) }\end{array}$ & 4 years & 7 years \\
\hline
\end{tabular}

* (Beijing Institute of Techmobg, 2001; Hunan University, 2001; Renumin University of China, 2001 ; Southern Yangtze University, 2001 ; Zhejiang University, 2001). 
Web-Based Education at Conventional Universities in China: A Case Study 24

Table 6: Use of ICT for Web-based Educational Programs

\begin{tabular}{|c|c|c|}
\hline University & Transmission Technology & Interactive Technology \\
\hline Tsinghua University & $\begin{array}{l}\text { Ku band of Asian Satellite } \\
\text { No.2; } \\
\text { China Education and Research } \\
\text { Network (CERNET); } \\
\text { Cable TV }\end{array}$ & $\begin{array}{l}\text { 2-way VSAT; ISDN; } \\
\text { Visual telephone; } \\
\text { Asynchronous } \\
\text { interaction via Intemet }\end{array}$ \\
\hline Peking University & $\begin{array}{l}\text { Intemet; } \\
\text { Xinnuo Satellite No.1; } \\
\text { IP broadcast coursewares }\end{array}$ & $\begin{array}{l}\text { Synchronous ISDN; } \\
\text { Asynchronous } \\
\text { interaction via Intemet }\end{array}$ \\
\hline $\begin{array}{l}\text { Beijing University of Posts } \\
\text { and Telecommunic ations }\end{array}$ & $\begin{array}{l}\text { ATM broadband multimedia } \\
\text { public telecommunications } \\
\text { network; } \\
\text { Intemet }\end{array}$ & $\begin{array}{l}\text { Synchronous interaction } \\
\text { via ATM; } \\
\text { Asynchronous } \\
\text { interaction via Intemet }\end{array}$ \\
\hline Zhejiang University & $\begin{array}{l}\text { Provincial SDH; } \\
\text { CERWET; } \\
\text { satellite and closed-circuit TV }\end{array}$ & $\begin{array}{l}\text { Synchronous } \\
\text { interactions via SDH, } \\
\text { CERNET and satellite; } \\
\text { Asynchronous } \\
\text { interaction via Intemet }\end{array}$ \\
\hline Hunan University & $\begin{array}{l}\text { ATM broadband multimedia } \\
\text { public telecommunications } \\
\text { network; } \\
\text { Internet }\end{array}$ & $\begin{array}{l}\text { Synchronous interaction } \\
\text { via ATM; } \\
\text { Asynchronous } \\
\text { interaction via Internet }\end{array}$ \\
\hline
\end{tabular}

Hote: Data are up to March 2001.

International Review of Research in Open and Distance Learning 